\title{
Transition Words Progression of Written Texts Made by the Second-Semester Students of the English Study Program of FKIP Saint Thomas University in Academic Year $2019 / 2020$
}

\author{
Fiber Yun Almanda Ginting \\ English Language Education Department, Faculty of Teacher Training and Education, Universitas \\ Katolik Saint Thomas, Indonesia \\ Email: Teozam@ymail.com
}

\begin{abstract}
This research is written to achieve an objective as follow: (1) to find out the progression of transitional in writing text has been made by the second semester of English Education Study Program in academic 2018/2019. The writer used descriptive qualitative research to give description systematically and factually about facts of a certain population. The researcher determines that the design is descriptive quantitative method because it describes the data that is taken from the sample, and the results of the data were tabulated in the form of percentage. There were 18 students (90\%) agreed that transition words were used to connect the sentences. There were 20 (100\%) students (90\%) agreed that transition words were used to organize the sentences. There were 17 students (85\%) agreed that transition words were used to remember about the topic. There were 20 (100\%) students agreed that transition words were used to tell the experience, and there were $20(100 \%)$ students agreed transition words were used to enhance the connections between facts.
\end{abstract}

Keywords: writing; transitional words; paragraph

\section{Introduction}

Writing in general provides a relatively permanent record of information, opinions, beliefs, personal experiences, feelings, arguments, explanations, and theories. For this reason, the writer must have a clear concept of what to convey to the readers and should be fully developed to the all the basic rules. Since the writing involves making an utterances visible. So, to make the audience or the reader understand their written production in the appropriate way, students or writers in general have to pay particular attention to their writing in terms of clarity, unity, different writing mechanics, word choice, and organization which all may lead to successful result by making their readers grasp the right intended meanings.

Many people have the mistaken idea that good writers simply sit down and write out a perfect letter, paragraph, or essay from start to finish. Good writing has a certain flow and natural progression. Transitional expression is essential to creating the progression and allowing the writer to connect ideas and introduce others. Additionally, they allow the writer to shift to a new idea, create contrast, opposition or emphasis, or to conclude the line argument.

Ruday (2016:61) transitional language is an important tool for effective narrative writing. By this strategy enables students to enhance the clarity of a narrative by establishing relationships between pieces of information, maximizing a piece's sense of flow, and illustrating the order in which events occur. 
A good writer will use this transitional expression to their advantage as they can introduce, reinforce and contradict ideas in a polished manner. It makes it much easier for the readers to follow on as they can tell what point we are trying to make with our next sentence. There are some kinds of transition signals; it can be transition signals between paragraphs or within paragraph. In the discussion of transition signals, Oshima and Hogue (1998:44-45) divided transition signals into three groups based on grammatical function. The three groups are sentence connectors, clause connectors, and mixed group called others. Those transition signals can be put in the beginning of sentences, in the middle of sentences and it can also appear in the end of sentence. They also divided transition signals into eight types. Those types are addition, contrast, comparison, example, cause effect, sequence and conclusion. In addition, Wingersky (1992:284) introduced some types of transition signals to add something, to show a contrast, to give an example, to compare or show similarity, to show time sequence, to emphasize, to show space relationship, and to summarize.

The researcher realized that it is important to improve students' skills in writing standard paragraphs because it is an important tool in their profession and for further education. Therefore, the writer performed a study to evaluate the writing skills of the Thirdsemester of English Education Study Program students in writing a paragraph in English in order to develop guidelines for correction and improvement of their writing skills.

\section{Review of Literatures}

\subsection{Writing}

Writing is a complex process consisting of many constituent parts which have to be considered. Ur (1996: 163) states writing is the expression of ideas, they conveying of message to the readers. Thus, the ideas and thoughts are informed into paragraph and have a meaning, so the readers can understand the meaning of the content. For students writing skills are extremelyimportant, because at the end of their studiesstudents should be able to write an academic paperand they moreovershould have a good competenceespecially in thesis writing(Kurniadi in Hafniati, 2020).

Furthermore, Zemach and Islam (2006:9) state writing is an important form of communication in day-to-day life, but it is especially important in secondary school and university. Writing can be defined as the act, process or activity of one who write something (Sari, 2020). Moreover, writing also one of the most difficult skills to master in both a first and second language. Students can find it challenging to find ideas to include in their writing, and each culture has its own style for organizing academic writing. Thus, writing in paragraph is designed to help low-intermediate students analyze model paragraph, find ideas for their writing, put their ideas into sentences, organize their sentences into paragraphs, review their paragraph, and revise their paragraphs so that they become even stronger. This process approach to writing will not only develop the students' paragraph writing skills, but also encourage them to become independent and creative writers.

In addition, Mayers (2005:2) state writing is an action, a process of discovering and organizing our ideas, putting them on paper, reshaping and revising them. In the same way, Byrne (1979:1) writing involves the encoding of a message of some kind: that is, we translate our thoughts into language.

\subsection{Writing Ability}

According to Yagelski (2015:48) state that writing ability is as much a function ofhow 
the writers respond to specific rhetorical situation, which are inherently social, as it is a result of individual skill. It means, the effectiveness as a writer depends not only on the effortwe put into a writing task but also on the way we put fit in and respond to the social situations in which we are completing the task.

\subsection{Teaching Writing}

According to Hyland (2003:99) teaching writing is not only about planning and making a course but it needs some orientations based on the aspects of writing in each organizing the writing teaching. The orientation on teaching is focusing on language structures, text function, and theme, creative expression, composing process, content and genre. In line with Hyland, Harmer (2007:38-39) proposes some strategies which can be considered by teachers in dealing with teaching of writing:

\section{a. The Way the Teacher Gets Students to Plan}

Before starting to write, the teacher may support students to think about what they want to write. The teacher can help students in building their knowledge before they start writing.

\section{b. The Way the Teacher Encourages Students to Draft, Reflect, and Revise}

The teacher can involve students to collaborative writing activity as it allows students to draft, reflect, and revise. This way enables students to respond to other students' writing.

\section{c. The Way the Teacher Responds to the Students}

At this point, the teacher can help students by giving suggestions to students' draft. Teacher's suggestion can be very useful to make some betterment in students' writing.

\subsection{Paragraph}

Many of the elements in longer pieces of writing such as essays are found in the paragraph. Thus, the paragraph is a good model to use before learning to write longer pieces. Feng-checkett and Checkett (2010: 133) state a paragraph is a group of sentences concerned with developing or expressing a single topic (one main idea). According to Zemach and Islam (2006:9) a paragraph is a group of about 6-12 sentences about one topic. Every sentence in a strong paragraph is about the same topic. All the sentences explain the writer the writer's main idea about the topic. Therefore, a paragraph can give information, tell an opinion, explain something, or even tell a short story. They also add specific information that in academic writing, a paragraph has a topic sentence that directly tells the reader the main idea. The other sentence in the paragraph, called supporting sentences, give more information about the topic.

\subsection{Writing Paragraph}

According to Feng-checkett and Checkett (2010: 133) the key to writing a good paragraph is to make it long enough to develop the topic. This paragraph is between four and fifteen sentences in length, and is describing the elements that make up the paragraph. There are five elements that we should consider in the paragraph: first, logical order of events, second, transitional expressions, third, the key concept repetition, fourth, substituting pronouns for nouns, and the fifth, parallelism.

\subsection{Transitional}

\section{a. Types of Transition}

According to Joshi (2014) there are two types of transitional expressions: (1) Transitional words, (2) Transitional Phrases. 
1. Transitional words that are used to link or join two or more clauses. Functioning as transitional words, conjunctive adverbs are commonly used to join independentclauses in compound sentences.

2. Transitional phrases are formed of 'group of words' and are used to join independent clauses in compound sentences.

\section{b. Using Transitional Expressions}

Joshi (2014) there are numerous transitional words and transitional phrases expression based on logical relationship they express:

1. List of Useful 'Transitional words' based on logical relationship they express:

(a) Addition: Besides, Further, Furthermore, Moreover

(b) Cause and Effect: Accordingly, Consequently, Therefore, Thus

(c) Comparison: However, Likewise, Nevertheless, Otherwise, Similarly, Still

(d) Concession: Certainly, Nonetheless

(e) Consequence (Result): Hence, Instead

(f) Contrast (Opposition) : Conversely, Instead

(g) Emphasis: Indeed

(h) Explanation: Namely, Specifically

(i) Final: Finally

(j) Sequence: Afterwards, Meanwhile, Next, Now, Previously, Subsequently, Then

2. List of useful 'Transitional Phrases' based on logical relationship they express:

(a) Addition: Addition

(b) Cause and Effect: As a consequence (or result)

(c) Comparison: In comparison

(d) Concession: On the other hand

(e) Contrast: After all, Even so, in contrast, on the contrary

(f) Emphasis: In fact

(g) Example: For example, For instance, In other words, That is

(h) Similarity: In the same way

(i) Summary: In conclusion

\section{Research Methods}

\subsection{Research Design}

In this study the writer used descriptive qualitative research to answer the problems statements that have been stated in the first chapter. Descriptive research is a method which involves observing and describing the data. The term descriptive research refers to the type of research question design and data analysis that will be applied to a given topic.

\subsection{Subject of Research}

This study conducted at Saint Thomas University of English Language and Education with the total sample 26 students at the second semester.

\subsection{Data Collecting}

In collecting the data in this study, the writer used some steps. The first one was by collecting the result of students' essays with the free topic. The second, finding the transitional used in each of essays made by the students. And the last, the writer collecting the classifying of the transitional that found in the students' sheet and arrange them based on the types and function, and in the analyzing of the data in this research, the writer read one by one of the students' writing sheet in order to find out the form of translation that used by student in assays text. 


\subsection{Data Analysis}

In analyzing the data in this study, the writer classified the form of transitional types that already formulated in chapter two. After the transition found in the assay text, the writer put them in the form of table list and describing the appropriateness of transitional in each assay. If the item of transitional correct or incorrect to connect the sentences in paragraph and how the transitional able to develop and connect the main idea and supporting sentence from one idea to another idea. The last steps, the writer calculating and counting the frequency of transitional appears in essays text.

\subsection{Data and Data Sources}

The data in this study could be categorized into event, place, person and informant or artifact. And the data source of this study that the writers used were information found in writing or documents.

\section{Results and Discussion}

\subsection{Results}

The data described in this finding was taken from the second semester of English Education Study Program in academic year 2018/2019 in their writing text. The title of their writing text were: Indonesian Education Now, Essay in National Examination, Should Students Take Part-time Jobs?, The Impact Quality of University in Era Millenial 4.0, and Full Day School. The data were analyzed in the form of qualitative as follows:

Table 1. Transitional Words for Adding Information and Emphasizing Ideas

\begin{tabular}{|c|c|c|c|}
\hline No. & $\begin{array}{l}\text { Transitional } \\
\text { words }\end{array}$ & Total & Text \\
\hline \multirow[t]{3}{*}{1.} & \multirow[t]{2}{*}{$\mathrm{Or}$} & \multirow[t]{2}{*}{9} & $\begin{array}{l}\text { Maybe you feel you are too old for fairs or you justdon't } \\
\text { like them. }\end{array}$ \\
\hline & & & $\begin{array}{l}\text { The world of education has intensified with the discourse } \\
\text { of the full school system or known as full day school. }\end{array}$ \\
\hline & \multicolumn{3}{|c|}{$\begin{array}{l}\text { Explanation: It showed the choice that the readers could follow that containing the } \\
\text { ideas. Sometimes, it could be the similarities between two things. For example: full } \\
\text { school system or full day school. }\end{array}$} \\
\hline \multirow[t]{3}{*}{2.} & \multirow[t]{2}{*}{ And } & \multirow[t]{2}{*}{50} & $\begin{array}{l}\text { And the only exception to reach the goal is a } \\
\text { knowledge. }\end{array}$ \\
\hline & & & $\begin{array}{l}\text { Every years, the students have already graduated from } \\
\text { seniority levels, and they will continuous study to the } \\
\text { university. }\end{array}$ \\
\hline & \multicolumn{3}{|c|}{$\begin{array}{l}\text { Explanation: It indicated the connection between tow sentences, generally with the } \\
\text { same grammatical function or type. It was used to provide a support condition with the } \\
\text { previous ideas. }\end{array}$} \\
\hline \multirow[t]{3}{*}{3.} & \multirow[t]{2}{*}{ In addition } & \multirow[t]{2}{*}{2} & $\begin{array}{l}\text { In addition, the government also needs to conduct } \\
\text { socialization to teachers to change the teaching methods } \\
\text { that are fun. }\end{array}$ \\
\hline & & & $\begin{array}{l}\text { In addition to the problem of cost, student awareness of } \\
\text { learning interest is lacking and facilities areinadequate. }\end{array}$ \\
\hline & \multicolumn{3}{|c|}{ Explanation: It introduced additional information for the previous ideas. } \\
\hline 4. & Also & 8 & The limitation on the number of teachers also seems to be a \\
\hline
\end{tabular}




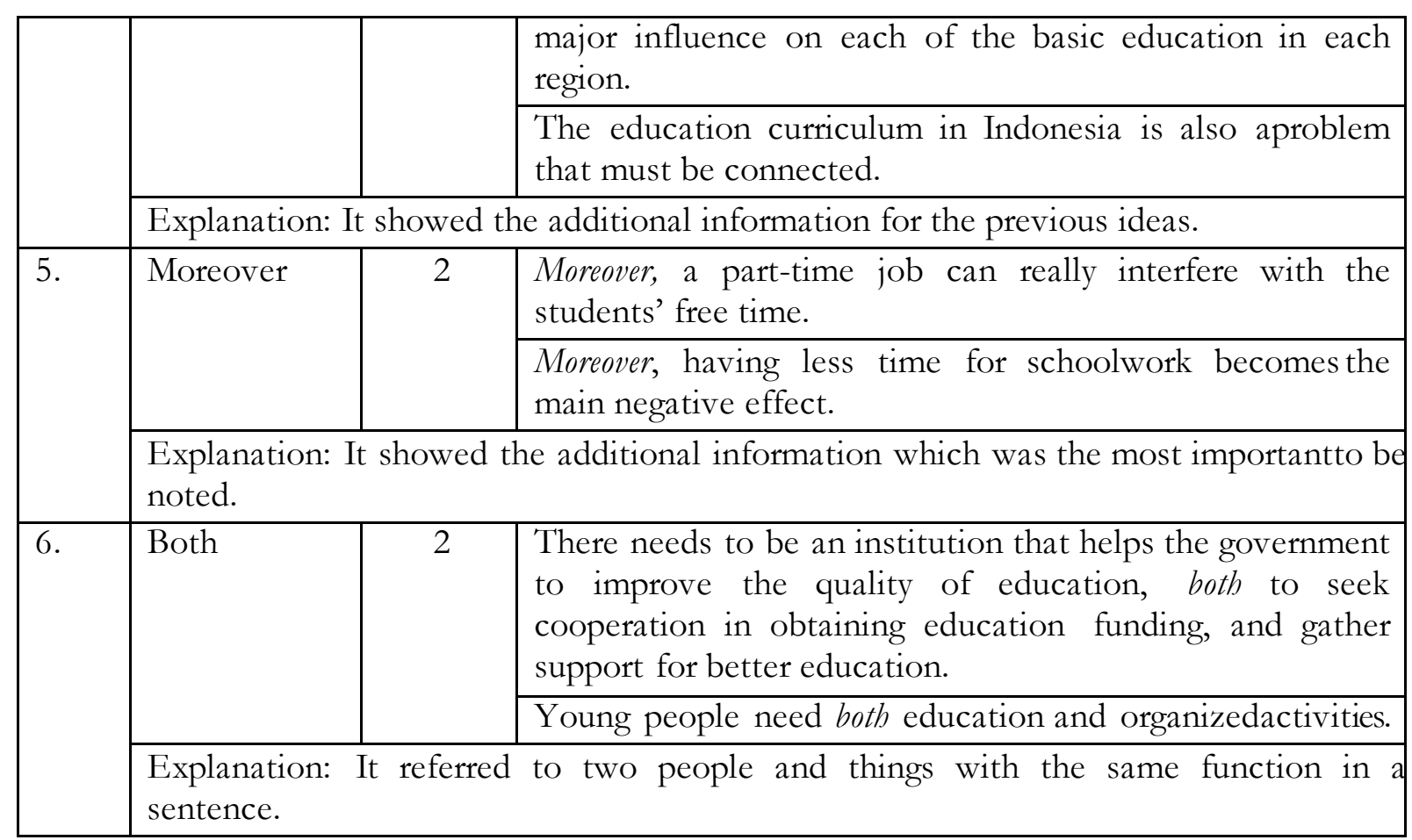

Table 2. Transitional Words for Showing Comparison and Contrast

\begin{tabular}{|c|c|c|c|}
\hline No. & $\begin{array}{l}\text { Transitional } \\
\text { words }\end{array}$ & Total & Text \\
\hline \multirow[t]{2}{*}{1.} & Among & 1 & $\begin{array}{l}\text { There are several reasons for the implementation of this } \\
\text { system, among others can shape the personality of students. }\end{array}$ \\
\hline & \multicolumn{3}{|c|}{ Explanation: This indicated the connection with or with a share for each of. } \\
\hline \multirow[t]{2}{*}{2.} & \multirow[t]{2}{*}{ However } & \multirow[t]{2}{*}{3} & $\begin{array}{l}\text { However, the policy carried out by the Minister of } \\
\text { Education and Culture was considered less effective in } \\
\text { paying attention to several aspects related. }\end{array}$ \\
\hline & & & $\begin{array}{l}\text { However, if Indonesia wants to be developed country, we must get the } \\
\text { better education first. }\end{array}$ \\
\hline & \multicolumn{3}{|c|}{ Explanation: It indicated on the other side of the fact given. } \\
\hline \multirow[t]{3}{*}{3.} & \multirow[t]{2}{*}{ But } & \multirow[t]{2}{*}{3} & $\begin{array}{l}\text { But in } 2010 \text {, there are } 1.080 .0000 \text { students quitted theirstudy } \\
\text { because of the high cost education. }\end{array}$ \\
\hline & & & I studied for the test, but I do not think I did well. \\
\hline & \multicolumn{3}{|c|}{ Explanation: It indicated 'unless' or the contradiction (sometimes followed by acause). } \\
\hline \multirow[t]{2}{*}{4.} & As well as & 1 & $\begin{array}{l}\text { The result of training and hard work of the teacher council as } \\
\text { well as the school committee who always upholds the } \\
\text { commitment to educate their students better. }\end{array}$ \\
\hline & \multicolumn{3}{|c|}{ Explanation: It indicated to the same extent, as much as. } \\
\hline \multirow[t]{3}{*}{5.} & \multirow[t]{2}{*}{ Consequently } & \multirow[t]{2}{*}{2} & $\begin{array}{l}\text { Consequently, many students who work part time fail to } \\
\text { perform at their best both on schoolwork and on } \\
\text { examination. }\end{array}$ \\
\hline & & & $\begin{array}{l}\text { Consequently, I need more time to prepare my lessontan } \\
\text { other people in my class. }\end{array}$ \\
\hline & & & , effect, or outcome. \\
\hline
\end{tabular}




\begin{tabular}{|c|c|c|c|}
\hline \multirow[t]{3}{*}{6.} & \multirow[t]{2}{*}{ Even } & \multirow[t]{2}{*}{4} & Even if you don't have much money, you don't have toworry. \\
\hline & & & $\begin{array}{l}\text { Education in Indonesia is still said to be not scattered even in } \\
\text { some areas there are places less teaching are still worthy. }\end{array}$ \\
\hline & \multicolumn{3}{|c|}{ Explanation: It indicated on the same level or still. } \\
\hline \multirow[t]{3}{*}{7.} & \multirow[t]{2}{*}{ Eventhough } & \multirow[t]{2}{*}{2} & $\begin{array}{l}\text { Even though you may be busy, you still want to relaxand have } \\
\text { fun with us. }\end{array}$ \\
\hline & & & $\begin{array}{l}\text { Even though the university has all facilities such as cupboard, } \\
\text { infocus, network, fan to support the students'skill. }\end{array}$ \\
\hline & \multicolumn{3}{|c|}{$\begin{array}{l}\text { Explanation: It indicated in spite of the fact that and used in introducingsubordinate } \\
\text { clause, which was often marked by ellipsis. }\end{array}$} \\
\hline \multirow[t]{2}{*}{8.} & Compared to & 1 & $\begin{array}{l}\text { Compared to other countries, Indonesia is still less in terms of } \\
\text { education when in the presence of decent education will grow } \\
\text { the acquisition of the nation. }\end{array}$ \\
\hline & \multicolumn{3}{|c|}{$\begin{array}{l}\text { Explanation: This indicated to examine two or more objects, ideas, people, etc, in orde } \\
\text { to note similarities and differences. }\end{array}$} \\
\hline \multirow[t]{3}{*}{9.} & \multirow[t]{2}{*}{ In line with } & \multirow[t]{2}{*}{2} & $\begin{array}{l}\text { This is in line with the definition of educationexpressed by } \mathrm{Ki} \\
\text { Hajar Dewantara. }\end{array}$ \\
\hline & & & $\begin{array}{l}\text { The skill and knowledge is in line with the students' } \\
\text { successes. }\end{array}$ \\
\hline & \multicolumn{3}{|r|}{ is indicated to take the same position with previous ideas or after ideas. } \\
\hline
\end{tabular}

Table 3. Transitional Words for Providing Example

\begin{tabular}{|l|l|c|l|}
\hline No. & $\begin{array}{l}\text { Transitional } \\
\text { words }\end{array}$ & Total & Text \\
\hline 1. & Such as & 3 & $\begin{array}{l}\text { Such as brawls, juvenile deliguency, radical } \\
\text { understanding, and so on. }\end{array}$ \\
\cline { 3 - 4 } & & $\begin{array}{l}\text { While in Indonesia, the number of people who get } \\
\text { education alone who get education is still far behind with } \\
\text { other countries, especially in disadvantages areas such as } \\
\text { NTB, NTT, Papua, and many other areas. }\end{array}$ \\
\hline 2. & Namely & 1 & $\begin{array}{l}\text { Even Indonesia itself is still inferior to our neighboring } \\
\text { countries, namely Malaysia and Singapore in the field of } \\
\text { education. }\end{array}$ \\
\cline { 2 - 4 } & Explanation: This indicated to introduces a sample of ideas. \\
\cline { 2 - 4 } & Explanation: This indicated to introduces a sample of ideas. \\
\hline
\end{tabular}

Table 4. Transitional Words for Showing Cause and Effect

\begin{tabular}{|c|c|c|c|}
\hline No. & $\begin{array}{l}\text { Transitional } \\
\text { words }\end{array}$ & Total & Text \\
\hline \multirow[t]{3}{*}{1.} & \multirow[t]{2}{*}{ So } & \multirow[t]{2}{*}{3} & $\begin{array}{l}\text { Another effect is that we have to find our way aroundthe } \\
\text { city, so we have to know the main parts of city. }\end{array}$ \\
\hline & & & $\begin{array}{l}\text { Life is choice, so it is the main reason why the studentsare } \\
\text { carefully to choose the best university, which can toimprove } \\
\text { and build their skill and knowledge for their future later. }\end{array}$ \\
\hline & \multicolumn{3}{|c|}{ Explanation: This indicated in order that or with the result that. } \\
\hline
\end{tabular}




\begin{tabular}{|l|l|c|l|}
\hline 2. & Therefore & 4 & $\begin{array}{l}\text { Therefore, today's education must be implemented with the } \\
\text { aim of guiding students to become better, not even } \\
\text { demanded outside their capacity. }\end{array}$ \\
\hline & $\begin{array}{l}\text { Therefore, the government needs to review before } \\
\text { implementing the policy. }\end{array}$ \\
\hline 3. & Because of & 3 & $\begin{array}{l}\text { There are 1.080.000 student quited their study becauseof the } \\
\text { high cost education. }\end{array}$ \\
\cline { 4 - 5 } & $\begin{array}{l}\text { The underdevelopment of education in these areas } \\
\text { because of unequal education in the state of Indonesia. }\end{array}$ \\
\hline
\end{tabular}

Table 5. Transitional Words for Providing Time Order and Sequence

\begin{tabular}{|c|c|c|c|}
\hline No. & $\begin{array}{l}\text { Transitional } \\
\text { words }\end{array}$ & Total & Text \\
\hline \multirow[t]{2}{*}{1.} & Lately & 1 & $\begin{array}{l}\text { Lately, the world of education has intensified with the } \\
\text { discourse of the full school system or known as full day } \\
\text { school. }\end{array}$ \\
\hline & \multicolumn{3}{|c|}{ Explanation: This indicated recently or not long since. } \\
\hline \multirow[t]{2}{*}{2.} & On the scopeof & 1 & $\begin{array}{l}\text { On the scope of the state, education is the maininstrument in } \\
\text { the information of future generation. }\end{array}$ \\
\hline & \multicolumn{3}{|c|}{$\begin{array}{l}\text { Explanation: This indicated the concentration of or the point of view about } \\
\text { something. }\end{array}$} \\
\hline \multirow[t]{3}{*}{3.} & \multirow[t]{2}{*}{\begin{tabular}{|l|l} 
Before & \\
\end{tabular}} & \multirow[t]{2}{*}{3} & $\begin{array}{l}\text { You'd better think a hundred times before you decide to } \\
\text { take a part time job. }\end{array}$ \\
\hline & & & $\begin{array}{l}\text { It depends on the students before they had given a } \\
\text { contribution to the university. }\end{array}$ \\
\hline & \multicolumn{3}{|c|}{$\begin{array}{l}\text { Explanation: This showed chronological order relation. This transitional words showed } \\
\text { the ideas in order of their occurrence in time. In this sentence, this transitional word } \\
\text { introduces one main thing that must be done before doing another thing. }\end{array}$} \\
\hline \multirow[t]{2}{*}{4.} & \begin{tabular}{l|l} 
Then &
\end{tabular} & 1 & $\begin{array}{l}\text { The school fair is a community event, and then processare } \\
\text { kept low. }\end{array}$ \\
\hline & \multicolumn{3}{|c|}{ Explanation: This indicated at the time or afterward. } \\
\hline
\end{tabular}

Table 6. Transitional Words for Summarizing

\begin{tabular}{|l|l|c|l|}
\hline No. & $\begin{array}{l}\text { Transitional } \\
\text { words }\end{array}$ & Total & Text \\
\hline 1. & In conclusion & 1 & $\begin{array}{l}\text { In conclusion, this is a bad situation if Indonesia wants to be } \\
\text { developed country, we must get the better education first. }\end{array}$ \\
\cline { 2 - 4 } & $\begin{array}{l}\text { Explanation: This indicated a summarization of paragraph. It was generallyattached in the } \\
\text { last sentence in a text. }\end{array}$ \\
\hline
\end{tabular}


Table 7. Transitional Words to Give a Purpose

\begin{tabular}{|c|c|c|c|}
\hline No. & Transitional words & Total & Text \\
\hline \multirow[t]{3}{*}{1.} & \multirow[t]{2}{*}{ As } & \multirow[t]{2}{*}{20} & $\begin{array}{l}\text { Most people consider National Examination as 'a } \\
\text { disaster' for the student as it is more difficult for them } \\
\text { to answer the items in the test. }\end{array}$ \\
\hline & & & $\begin{array}{l}\text { Education is the strongest way to be survive as the key } \\
\text { to assess of someone's successes. }\end{array}$ \\
\hline & \multicolumn{3}{|c|}{ Explanation: This indicated the result of something with its reason. } \\
\hline \multirow[t]{3}{*}{2.} & \multirow[t]{2}{*}{ So that } & \multirow[t]{2}{*}{4} & $\begin{array}{l}\text { Education is able to guide all natural forces that exist in } \\
\text { learners, so that later they can become humans who are } \\
\text { able to achieve the highest safety and happiness in life. }\end{array}$ \\
\hline & & & $\begin{array}{l}\text { All have an impact on education in Indonesia so that it } \\
\text { becomes uneven and left behind to compete with other } \\
\text { countries. }\end{array}$ \\
\hline & \multicolumn{3}{|c|}{$\begin{array}{l}\text { Explanation: This indicated as a subordinate clause to show a purpose or to give an } \\
\text { explanation. In the format Sentence } 1 \text {, "so that" Sentence } 2 \text {, the first sentence was the } \\
\text { action/cause and the second was the intended result/effect. }\end{array}$} \\
\hline
\end{tabular}

Table 8. Transitional Words to Add another Point

\begin{tabular}{|c|c|c|c|}
\hline $\begin{array}{l}\mathbf{N} \\
\mathbf{o}\end{array}$ & $\begin{array}{l}\text { Transitional } \\
\text { words }\end{array}$ & Total & Text \\
\hline \multirow[t]{2}{*}{1.} & $\begin{array}{l}\text { In } \\
\text { accordance } \\
\text { with }\end{array}$ & 1 & $\begin{array}{l}\text { In accordance with the policy put forward by Muhadjir } \\
\text { Effendi as Minister of Education and Culture who said } \\
\text { that students would be at school from } 07.00 \text { to } 17.00 \text {. }\end{array}$ \\
\hline & \multicolumn{3}{|c|}{ Explanation: This indicated a way that agreed with or followed something. } \\
\hline \multirow[t]{3}{*}{2.} & \multirow[t]{2}{*}{$\begin{array}{l}\text { Based on the } \\
\text { fact }\end{array}$} & \multirow[t]{2}{*}{2} & $\begin{array}{l}\text { Based on the fact, the education which as the main } \\
\text { factor to build the great generation. }\end{array}$ \\
\hline & & & $\begin{array}{l}\text { Based on the order of the best tertiary institutions in } \\
\text { Indonesia, Universitas Indonesia ranks first. }\end{array}$ \\
\hline & \multicolumn{3}{|c|}{ Explanation: This indicated to follow something according to. } \\
\hline \multirow[t]{3}{*}{3.} & \multirow[t]{2}{*}{ In line with } & \multirow[t]{2}{*}{2} & $\begin{array}{l}\text { This is in line with the definition of educationexpressed } \\
\text { by Ki Hajar Dewantara. }\end{array}$ \\
\hline & & & $\begin{array}{l}\text { The school committee always upholds the commitment } \\
\text { in line with the education to better for students. }\end{array}$ \\
\hline & \multicolumn{3}{|c|}{ Explanation: This indicated with similar to, or at the same level as something. } \\
\hline \multirow[t]{3}{*}{4.} & \multirow[t]{2}{*}{ In order to } & \multirow[t]{2}{*}{2} & $\begin{array}{l}\text { In order to conduct this type of evaluation, the teacher or } \\
\text { the test maker need to provide some possible answerthat } \\
\text { may occur during the test. }\end{array}$ \\
\hline & & & $\begin{array}{l}\text { In order to get an easy access to knowledge, university } \\
\text { provides the students the complete facilities. }\end{array}$ \\
\hline & \multicolumn{3}{|c|}{$\begin{array}{l}\text { Explanation: This indicated to express the purpose of something. Adding 'inorder } \\
\text { to' made the sentence feel more natural and easier to read. }\end{array}$} \\
\hline \multirow[t]{2}{*}{5.} & Besides that & 1 & $\begin{array}{l}\text { Besides that another achievement that was no less proud, } \\
\text { was the champion in the field of sport, arts, and } \\
\text { environment. }\end{array}$ \\
\hline & \multicolumn{3}{|c|}{ Explanation: This indicated together with or as well as. } \\
\hline
\end{tabular}


Table 9. Transitional Words to Show a Result

\begin{tabular}{|l|l|l|l|}
\hline No. & $\begin{array}{l}\text { Transitional } \\
\text { words }\end{array}$ & Total & Text \\
\hline 1. & According to & 1 & $\begin{array}{l}\text { According to Ki Hajar Dewantara, education is defined as a } \\
\text { guide in human growth. }\end{array}$ \\
\cline { 2 - 4 } & Explanation: This indicated in conformity with or as stated by or depending on. \\
\hline 2. & Based on & 2 & $\begin{array}{l}\text { Based on the fact, the government only builds educational } \\
\text { facilities in urban areas. }\end{array}$ \\
\cline { 3 - 4 } & $\begin{array}{l}\text { Based on the fact, the limitation on the number ofteachers also } \\
\text { seems to be a major influence on each of the basic education } \\
\text { in each region. }\end{array}$ \\
\cline { 2 - 4 } & Explanation: This indicated in conformity with or as stated by or depending on. \\
\hline
\end{tabular}

Table 10. Transitional Words to Show Restriction

\begin{tabular}{|l|l|c|l|}
\hline No. & $\begin{array}{l}\text { Transitional } \\
\text { Words }\end{array}$ & Total & \multicolumn{1}{c|}{ Text } \\
\hline 1. & In terms of & 1 & $\begin{array}{l}\text { In terms of university, clever and exceptional lecturers become } \\
\text { a teaching team that plays a role in shaping the quality of } \\
\text { their students. }\end{array}$ \\
\cline { 2 - 4 } & $\begin{array}{l}\text { Explanation: This indicated the specifying which aspect writer wanted to discussor form } \\
\text { what point of view the readers were considering the ideas. }\end{array}$ \\
\hline 2. & $\begin{array}{l}\text { On the } \\
\text { positive/ } \\
\text { negative side }\end{array}$ & $\begin{array}{l}\text { On the negative side, working and still maintaining agood grade } \\
\text { at school is not an easy task. }\end{array}$ \\
\cline { 2 - 3 } & $\begin{array}{l}\text { On the negative side, education in Indonesia is still quite far } \\
\text { behind education in other countries in the world. }\end{array}$ \\
\cline { 2 - 4 } 3. & $\begin{array}{l}\text { Explanation: This indicated on the contrary of the contrast between the previousidea. } \\
\text { also.. }\end{array}$ \\
\hline & $\begin{array}{l}\text { Explanation: This indicated the parallelism between tow ideas. It was used toconnect } \\
\text { and emphasize two phrases or two words in the same position. } \\
\text { students, but also for the teachers. }\end{array}$ \\
\hline
\end{tabular}

Dealing with the research question number 1 about the progression of transitional words in writing text by the second semester of English Education Study Program in academic year 2018/2019, the writer found the several reasons why the students use transitional words. Below were the contributions of why the students using transitional words in writing text:

\section{Connect the Sentences}

Based on 20 students, there were 18 students (90\%) agreed that transition words could be used to connect the sentences in paragraph. They would easy to put the ideas or supportingdetails by using the transition words. Then, the students could easily attract the reader's attention by providing the supporting details to support the time as it had mentioned before.

\section{Organize the Sentences}

Based on 20 students, there were 20 students (100\%) agreed that transition words 
could beused to arrange the sentences in writing text. It was the way to organize the idea and supporting details in each paragraph. Moreover, they believed that the readers would easy to follow their ideas.

\section{Remember about the Topic}

Based on 20 students, there were 17 students (85\%) agreed with the function of transition words because it as related with the topic given in the text. It was a necessity to explain the topic in the beginning, middle, or last paragraph in their writing text easily. For example: Firstly in the beginning paragraph or In conclusion to summarize paragraph.

\section{Tell the Experience}

Based on 20 students, there were 20 students (100\%) agreed that transitional words were used to tell the experience. The function was to arrange the ideas in a chronological order, so that the students felt easy to determine the general issue to specific issue for their writing text. The essay would interest the readers if the writer had a good ability in organizing the ideas.

\section{Enhance the Connections between Facts}

Based on 20 students, there were 20 students (100\%) agreed that transitional words were used to enhance the connections between facts. It helped to provide strong evidence in argumentative papers or added some interesting details in narrative or descriptive essays. It could develop students' writing significant points to readers by referencing relevant materials from previous paragraph to connect all paragraphs.

\section{Strengthen the Topic and Ideas}

Based on 20 students, there were 18 students (90\%) agreed that transition words could be used to strengthen the topic and ideas. It was used to describe a consequence or implication of the idea in the preceding paragraph. The transition words linked the relationship between the new information and the known information.

\subsection{Discussion}

Based on the analysis of data, the results of research were described as follows:

There were 152 transitions as a total used of ten types of transitions used by the second semester of English Education Study Program in academic year 2018/2019. Those were transitional word namely addition for ideas, comparison and contrast, example, cause and effect, time order and sequence, summarize, purpose, add another point, result, and restriction. The result of analysis found that the progression of transitional words in writing text by the second semester of English Education Study Program in academic year 2018/2019. There were several reasons why the students using transitional words in writing text, such as: (1) Students agreed that transition words were used to connect the sentences with percentage 90\% (18 students), with the following explanations: (a) They would easy to put the ideas or supporting details by using the transition words, (b) The students could easily attract the reader's attention by providing the supporting details to support the time as it had mentioned before. (2) Students agreed that transition words were used to organize the sentences with percentage 100\% (20 students), with the following explanations: (a) It was the way to organize the idea and supporting details in each paragraph, (b) They believed that the readers would easy to follow their ideas. (3) Students agreed that transition words were used to remember about the topic with percentage $85 \%$ (17 students), with the following explanations: (a) It was a necessity to explain the topic in the beginning, middle, or last paragraph in their writing text easily. For example: Firstly in the beginning paragraph or In conclusion to summarize paragraph. (4) Students agreed that 
transition words were used to tell the experience with percentage 100\% (20 students), with the following explanations: (a) The function of transition words was to arrange the ideas in a chronological order, so that the students felt easy to determine the general issue to specific issue for their writing text, (b) The essay would interest the readers if the writer had a good ability in organizing the ideas. (5) Students agreed that transition words were used to enhance the connections between facts with percentage $100 \%$ (20 students), with the following explanations: (a) It helped to provide strong evidence in argumentative papers or added some interesting details in narrative or descriptive essays, (b) It could develop students' writing significant points to readers by referencing relevant materials from previous paragraph to connect all paragraphs. (6) Students agreed that transition words were used to enhance the connections between facts with percentage $90 \%$ (18 students), with the following explanations: (a) It was used to describe a consequence or implication of the idea in the preceding paragraph, (b) The transition words linked the relationship between the new information and the known information.

\section{Conclusion}

The total of transitional words that were used by 20 students of the second semester of English Education Study Program in academic year 2018/2019 in their writing text was 152 transitional words. The result of analysis found that the progression of transitional words in writing text. There were several contributions of why the students using transitional words in writing text, such as: (1) Students agreed that transition words were used to connect the sentences with percentage $90 \%$ (18 students), with the following explanations: (a) They would easy to put the ideas or supporting details by using the transition words, (b) The students could easily attract the reader's attention by providing the supporting details to support the time as it had mentioned before. (2) Students agreed that transition words were used to organize the sentences with percentage 100\% (20 students), with the following explanations: (a) It was the way to organize the idea and supporting details in each paragraph, (b) They believed that the readers would easy to follow their ideas. (3) Students agreed that transition words were used to remember about the topic with percentage $85 \%$ (17 students), with the following explanations: (a) It was a necessity to explain the topic in the beginning, middle, or last paragraph in their writing text easily. For example: Firstly in the beginning paragraph or In conclusion to summarize paragraph. (4) Students agreed that transition words were used to tell the experience with percentage 100\% (20 students), with the following explanations: (a) The function of transition words was to arrange the ideas in a chronological order, so that the students felt easy to determine the general issue to specific issue for their writing text, (b) The essay would interest the readers if the writer had a good ability in organizing the ideas. (5) Students agreed that transition words were used to enhance the connections between facts with percentage 100\% (20 students), with the following explanations: (a) It helped to provide strong evidence in argumentative papers or added some interesting details in narrative or descriptive essays, (b) It could develop students' writing significant points to readers by referencing relevant materials from previous paragraph to connect all paragraphs. (6) Students agreed that transition words were used to enhance the connections between facts with percentage 90\% (18 students), with the following explanations: (a) It was used to describe a consequence or implication of the idea in the preceding paragraph, (b) The transition words linked the relationship between the new information and the known information. 


\section{References}

Byrne, D. 1979, Teaching Writing Skills. London: Longman.

Feng-checkett, G., \& Checkett, L. 2010. The Write Start: Sentences to Paragraphs withProfessional and Student Readings. New York.

Hafniati, Sari, R., and Pujiastuti, S. (2020). Developing of Thesaurus Software to Increase the Writing Quality of the Thesis of the Students at the German Language Department. Britain International of Linguistics, Arts and Education(BIoLAE) Journal Vol.2 (1):346-352.

Hyland, K. 2003. Second Language Writing, London: Cambridge University.

Joshi, M. 2014. Common English Sentences: English in Daily Life. South Carolina: Createspace Independent Publishing Platform.

Mayers, A. 2005. Gateways to Academic Writing: Effective Sentences, Paragraphs, andEssays, London: Longman.

Oshima, A., \& Hogue, A. 1998, Writing Academic English. London: Longman.

Ruday, S. 2016. The Narrative Writing Toolkit: Using Mentor Texts in Grades 3-8. New York: Routledge.

Sari, I., Pulungan, A.H., and Husein, R. (2020). Students' Cognition and Attitude in Writing Descriptive Text. Britain International of Linguistics, Arts and Education (BIoLAE) Journal Vol. 2 (1): 395-404.

Ur, P. 1996. Five-Minute Activities: A Resource Book of Short Activities. London: Cambridge University Press.

Wingersky, J., Boerner, J., \& Balagh, D. 1992: Writing Paragraph and Essay: Integrating Reading, Writing, and Grammar Skills. California: WardsworthPublising Company.

Yagelski, R. 2015. Writing: Ten Core Concepts, New York: Albany University Press.

Zemach, D. \& Islam C. 2006. Writing Paragraphs: From Sentence to Paragraph. Australia: Macmillan Education. 